\title{
THE LANGUAGE ECOLOGY OF A NEW AFRIKAANS BIBLE
}

\author{
F. Ponelis ${ }^{1}$
}

\begin{abstract}
Three sets of codes are germane to a current Afrikaans Bible translation: Dutch, English and varieties of Afrikaans, especially Standard Afrikaans. Dutch was established as a local language of culture in the Dutch era from 1652 to 1806 . The sweeping transformation of Cape society by British colonial rule gave great impetus to Dutch as a local language of culture. On account of religious language conservatism, which considers an elevated and exclusive code important, the local Dutch church had a powerful vested interest in Dutch. The English linguistic and cultural tradition that penetrated the local Dutch-Afrikaans church in the nineteenth century had an increasing impact. The Afrikaans Bible is translated in Standard Afrikaans. Both the ideological connection of this code with Afrikaner nationalism and its marked divergence from varieties of colloquial Afrikaans are relevant to a new Afrikaans Bible translation.
\end{abstract}

Over the past one hundred years the translation of the Afrikaans Bible has evolved markedly from the activity of a restricted and exclusive group into an industry. This industry functions within a context in which numerous social and cultural powers play an important role.

Three different codes play an important role in the Afrikaans Bible translation: Dutch, English and Standard Afrikaans. The Afrikaans Bible stemmed from a Dutch tradition. The Afrikaans vernacular language was established by the beginning of the 18th century (Ponelis 1993, and the extensive literature cited there). Afrikaans developed within the multilingual Cape society from the Dutch colloquial language which was established at the Cape. The Dutch spoken language established in the Cape in the 17th century differed greatly from the formal, written Dutch language of that time.

\begin{tabular}{|l|l|l|}
\hline Cape Nederlands & Formal Nederlands & English \\
\hline Johanna het haar gesien & Johanna heeft haar gezien & Johanna saw her \\
\hline die man, die boom & de man, de boom & the man, the tree \\
\hline
\end{tabular}

1 Prof. Fritz Ponelis, Department of Afrikaans and Dutch, University of Stellenbosch. 


\begin{tabular}{|l|l|l|}
\hline koppie, bakkie & kopje, bakje & hillock, small bowl \\
\hline klip, kombuis & steen, keuken & stone, kitchen \\
\hline perd, kers & paard, kaars & horse, candle \\
\hline woes, vergenoeg & woest, vergenoegd & desolate, satisfied \\
\hline
\end{tabular}

This difference was enhanced by creolisation, i.e. the influence which speakers of foreign languages, namely the many slaves, had on Dutch which they had to master quickly and under difficult social circumstances. The social structure was not sufficiently stable for a full implementation of Dutch at the Cape. This resulted in the simplification of the complex grammatical systems of Dutch, including the conjugation of the verb and the difference between de-nouns (de arm, de kerk) and het-nouns (het been, het begin).

Until the end of the 19th century both codes functioned simultaneously within the Afrikaans-language community. On the one hand, there was High Dutch: the principal, formal written and reading language. Only a small group of people used this code owing to the Afrikaans speakers' low literacy in the 18th century. The majority of writings of the time suggests that Afrikaans-speaking people had an extremely poor command of the Dutch written language. On the other hand, there was the Afrikaans spoken language, which was known as Hollands.

This situation, in which the high code (the language of culture) differed greatly from the lower code (the vernacular language), is known as diglossia. This phenomenon is widespread throughout the world, as well as in Western Europe and in areas where the Dutch language is spoken. Contemporary Standard Dutch for example differs greatly from the Western Flemish of the northern Belgian coastal region or the Limburgs of Maastricht.

Cape diglossia was no different, but there were important differences in degree. The rift between the higher and the lower code at the Cape widened considerably as a result of language contact and creolisation on the lower code. The quality of education at the Cape was poorer than that in The Netherlands, and the degree of literacy was therefore much lower, making the higher code much less accessible to the wider population. In addition, the language of the current Dutch Bible, the State translation, was more formal than the Dutch language of culture of that time.

The State translation was published in 1637 , at the time when the earlier New Dutch written language in northwestern Netherlands gained status in the works of Hooft, Vondel, Huygens and Revius. Between the end of the 16th and the beginning of the 17th century the focus of the Dutch world shifted from Antwerp in the south to Amsterdam in the north. 
This norm shift is obvious in the language of the State Bible due to the influence of translators and theologians from the southern Netherlands. It must be borne in mind that the Dutch Reformation spread from south to north. From the start of the rebellion against Spain (the Eighty Years War) most of the southern elite emigrated to the north. This elite took the lead in the economic, cultural, as well as theological fields and contributed markedly to the translation of the State Bible. An important result of this was the stately and even archaic content of the State Bible's Dutch.

Genesis 1: 1-10 in the State Bible of 1637

1. In den beginne schiep Godt den hemel / ende de aerde.

2. De aerde nu was woest ende ledigh / ende duysternisse was op den afgront: ende de Geest Godts sweefde op de wateren.

3. Ende Godt seyde: Daer zy licht: ende daer wert licht.

4. Ende Godt sagh het licht / dat het goet was: ende Godt maeckte scheydinge tusschen het licht / ende tusschen de duysternisse.

5. Ende Godt noemde het licht dagh / ende de duysternisse noemde Hy nacht: Doe was het avond geweest / ende het was morgen geweest / de eerste dagh.

6. Ende Godt seyde: Daer zy een uytspansel in't midden der wateren; ende dat make scheydinge tusschen wateren / ende wateren.

7. Ende Godt maeckte dat uytspansel: ende maeckte scheydinge tusschen de waterend die onder het uytspansel sijn / ende tusschen de wateren die boven het uytspansel zijn: ende het was alsoo.

8. Ende Godt noemde het uytspansel / hemel: doe was het avont geweest / ende 't was morgen geweest / de tweede dagh.

9. Ende Godt seyde: Dat de wateren van onder den hemel in eene plaetse vergadert worden / ende dat het drooge gesien worde: ende het was alsoo.

10. Ende Godt noemde het drooge / aerde / ende de vergaderinge der wateren noemde $\mathrm{Hy} /$ zeen: ende Godt sagh dat het goet was.

Without creating a false picture of the piety of Cape society, it can be accepted that if the State Bible was the most widely read text at the early Cape - provided a person was literate enough to read - then this degree of literacy was both formed by and directed to the State Bible. The result was that the Dutch reading language with which the inhabitants of the Cape came into contact differed considerably from the vernacular language. The language of the State Bible was also the language for catechisms and church hymns.

The Afrikaans Bible stemmed from the Dutch reformed tradition. The church at the Cape was an institution within the Dutch East India Compa- 
ny (VOC). Its ministers were Company officials, and the VOC supervised the formation of church boards and the way in which church board meetings were run. Although the early Cape population was of different Christian persuasions, including the Roman and Lutheran Churches, the VOC recognised only the Reformed Church (Gereformeerde Kerk). At the end of the 18th century, the staunch Lutherans were eventually granted permission by the VOC to build the Lutheran Church in Cape Town. This situation remained unchanged into the 19th century when various other church denominations, among others the Sabbatarians, Presbyterians, Methodists and Anglicans, established themselves at the Cape.

After the British colonial power put an end to the Dutch period at the Cape and until the Theological Seminary was established at Stellenbosch in 1859, The Netherlands remained an important source of Cape ministers. Various informative and theological writings from The Netherlands were distributed at the Cape.

During the 19th century, the British authority radically changed the spartan Cape Dutch society and established more stable organisations, including the church, education and the media. Dutch thrived in a more stable, established society. By the end of the 19th century Dutch was finally established as a local cultural language, not only in the Cape, but also in the northern republics.

The First Afrikaans Language Movement evolved as an attempt to translate the Bible into Afrikaans. At first this movement was not about promoting Afrikaans in general as a written language, but about an Afrikaans Bible translation in particular. S.J. du Toit's ideal was to have the Bible translated into Afrikaans, and he persevered in making draft translations.

However, the campaign to promote Afrikaans as a cultural and written language began rather inauspiciously. The Afrikaans-speaking intellectual elite of that time, in particular the church leadership, was convinced that Dutch, and not Afrikaans, was the language of culture and in particular of the Bible, and that it should be the church language of the Afrikaans-speaking people. There was an effective opposition to Afrikaans as the language of worship, and the first attempt at an Afrikaans Bible translation failed.

Both the Dutch and the English linguistic and cultural traditions are important for the Afrikaans Bible translation. The British occupation led to an English linguistic and cultural revolution at the Cape. In the religious sphere this cultural transformation affected the reformed tradition. The British authority provided a stronger organisational foundation for the church. By 1806 there were only ten congregations at the Cape, and this fi- 
gure doubled within approximately three decades. By introducing a reasonably large number of ministers from the Scottish Presbyterian Church, the British authorities tried to accommodate the reformed tradition whilst attempting to promote English. The so-called liberal theological tradition in The Netherlands led to the unpopularity of ministers from The Netherlands at the Cape, and the local church preferred the Scottish Presbyterians (Van der Watt 1980:27ff.). During the 19th century English gained a strong foothold in the Cape Reformed Church in that various congregations held English services (Scholtz 1965).

Beyond the Reformed Church, denominations such as the Anglican and Methodist churches led to the popularity of English in the religious life of the Afrikaans-speaking community. The tendency among Afrikaans-speaking people to feel at home in English-speaking denominations is as strong today, in particular as far as the influence of those of charismatic persuasion is concerned. As a result, Afrikaans-speaking people read various English Bible translations and a large variety of informative literature in English. The gospel as well as spiritual songs and hymns introduced English into Afrikaans worship services.

The Afrikaans Bible translation lies within the framework of Standard Afrikaans. The standardisation of Afrikaans began in earnest immediately following the Anglo-Boer War. At the end of the 19th century, S.J. du Toit and the Paarlse Drukpers did important preparatory work, but this attempt at standardisation was foiled by the Afrikaans-speaking cultural and religious elite's marked preference for Dutch.

The cultural usage of Afrikaans had developed considerably before the official recognition of Afrikaans in 1925. By that time a large number of scientific and literary works were available in Afrikaans and the Afrikaans media had come of age. The late publication of the first Afrikaans Bible translation of 1933 was due to the conservatism of church leaders and members who had adhered to Dutch.

This language conservatism is an important language ecological power. There is a strong tendency to view religious language as sacred. In ancient Hinduism Sanskrit is regarded as the sacred language. Attempts have been made to resist language change in Sanskrit, so that a specific form of this language will remain associated with Hinduism. The attempt to "freeze" Sanskrit necessitated exhaustive language description, which boosted linguistics in ancient India substantially. In Islam other languages are often used to convey the fundamental doctrines of the faith. In South Africa English is the most prominent Islamic auxiliary language, and Afrikaans was widely used as an Islamic auxiliary language until the middle of the last 
century. But Islam knows only one sacred language, viz. Arabic, and only one form of that language, the classical Arabic of the Koran, which differs considerably from modern-day Arabic vernaculars.

Conservatism is also well known in the language of the Christian Church. Latin was and still is to some extent the language of the Roman Catholic Church. Old Church Slavic fulfilled a similar function in the Russian Orthodox Church.

Language conservatism has led to the English King James Version and the Dutch State Bible still being used — although in a limited circle — and to Dutch suriving for so long in the local church. The influence of the Dutch tradition was so strong that the 1933 translation adhered very closely to the State Bible. This translation and the first Psalter are teeming with Netherlandisms, a great many of which are so hyperformal and archaic that there is no trace of them in the Dutch vernacular, e.g. aangesig, spreek, voorwaar, vlees, psalmsing, goedertierenheid, gunsgenoot, welgeluksalig, geformeer, verlustiginge, welbehae, drekgod, verheug, grimmigheid, stier, leërskare, arbei, diensmaagd, werp, broeder, lewenswandel, herder, lankmoedig, eersgeborene, owerpriester, deelgenoot, in toorn ontbrand, wees nie bevrees nie, die eerstelinge van jou koring, laat julle hart nie week word nie, jou met iemand verloof, die skerpte van die swaard, geloofd sy die Here, veelheid, weë soos een wat baar, gesnede beeld, gedenk die sabbatdag, in bul midde staan, deur die menigte van visse, 'n tweesnydende swaard.

A language exists in different forms, known as varieties. Some of the varieties of Afrikaans are Standard Afrikaans, the Afrikaans vernacular, the flaaitaal of young urban Blacks, Cape Afrikaans, the Afrikaans of Namaqualand, Legal Afrikaans and the Afrikaans pulpit language. Regardless of its importance, the standard language is but one of the great number of varieties.

The Afrikaans culture language or Standard Afrikaans is the inclusive and prestigious variety of Afrikaans (Ponelis 1998). A standard language is the only inclusive or commonly accepted variety of a language in a specific language community. Standard Afrikaans is inclusive to the extent that it is accessible to all users of Afrikaans. Its specific varieties, including its dialects, are confined to specific users of Afrikaans. Northwestern Afrikaans is confined to a specific region, flaaitaal to "townies" and prison language to convicts and ex-convicts, but in principle Standard Afrikaans is accessible to all users of Afrikaans, and that includes non-mother-tongue speakers. The extent to which Standard Afrikaans is accessible actually depends on whether the areas in which this variety is used, are within the reach of actual and potential users of Standard Afrikaans. 
A factor of significant importance to inclusivity is ideology. The standardising of a language is an enormous, time-consuming, expensive and complex process requiring strong ideological motivation. In the case of Afrikaans this motivation was Afrikaner nationalism, which unfortunately used Standard Afrikaans exclusively to gain and maintain powers and privileges for a particular group of Afrikaans users whilst it excluded a large group of other users. In recent decades a powerful resistance has manifested against the association between Standard Afrikaans and Afrikaner nationalism.

An important form of this opposition is the endeavour towards re-standardising Afrikaans, towards creating a new Standard Afrikaans, e.g. to change the dialect basis of Standard Afrikaans, by restandardising Standard Afrikaans on for example the south-western (Cape) variety (Snyders 1987) or other varieties (Van Rensburg 1991). This reasonably radical suggestion is genuine because, as standard languages develop, their dialectal basis can change even drastically. A particularly good example is the case of Standard Dutch. Until the 16th century the Dutch culture language was to a large extent based on the southern (particularly Brabant) varieties, and the centre of the Dutch language region was the flourishing harbour city of Antwerp. From the second half of the 16th century the province of Holland and the city of Amsterdam assumed control of the Dutch language region. As a result Standard Dutch developed a strong northern and Hollandic component. It is important to note that this change was an offshoot of a comprehensive economic and social revolution. The advantage of "Cape"-ising the Afrikaans culture language is that the new Standard Afrikaans will be made more accessible to a large number of users. However, this will also alienate users of other varieties. Furthermore, the southwest lacks the money and drive to persuade the entire Afrikaans language community into accepting a new Standard language.

Standard Afrikaans is also prestigious. The status of Standard Afrikaans is linked to its institutionalisation as an official language and its use in the public sphere, including science, law, the media, as well as literature, administration, and education. From a purely linguistic perspective, the Afrikaans vernacular and in particular the dialects are regarded as the standard language, but they lack the respect of Standard Afrikaans due to their use in the private sphere or in the family and circle of friends. The difference in domain between Standard Afrikaans and the Afrikaans vernacular is substantiated by the fact that Standard Afrikaans is used as written language and the Afrikaans vernacular to a large extent as spoken language. In other words, the standard language is stylistically more formal than the ver- 
nacular. In conclusion Standard Afrikaans is prestigious due to its differentiated content and in particular its rich lexicon which enables this variety to be used in a modernised society. Nevertheless, the status of Standard Afrikaans is undermined by its connection with Afrikaner nationalism and the higher prestige of Standard English.

The general Afrikaans vernacular and the opposition to the Afrikaner nationalistic ideology have raised the serious questioning of the existence of Standard Afrikaans. In a contribution to Ritsbrief 8 (May 2001) of The Afrikaans Language Secretariat Koos Kombuis formulates this as follows (translated):

There is no longer such a thing as Standard Afrikaans [in existence] ... To speak the truth, there never was such a thing: Afrikaans, the complete language as it is, is actually a form of Plat-Hollands. Or Mixed-Hollands perhaps.

We are weeds. We are a kitchen language. The whole idea that there is a certain type of Afrikaans which is somehow lifted above other dialects of Afrikaans, goes against the very spirit of Afrikaans itself.

Our whole cultural heritage is based on loan words. That is all that differentiates us from our European ancestors. Loan words from English, German, Malay, French, sailor language, slave language, even Hottentot. If there is a problem with a lopsided predominance of one sort of loanword - namely from English - it is the N.P.'s f... fault (here I may swear). If it were not for forty years of Apartheid, our language would now be shot through with loan words from Xhosa and Zulu in stead of being annexed by English.

The diglossia between the Afrikaans vernacular and Standard Afrikaans is motivated on the one hand by the over-cultivation of Standard Afrikaans and on the other hand by the profound English influence on the Afrikaans vernacular. Standard Afrikaans is over-cultivated and hyperformal due to the over-influence of formal Dutch. Archaic and hyperformal Dutch words and expressions are listed in Afrikaans dictionaries and included in the 1933 Bible translation. In the following list, the forms in parentheses represent the less formal variants: aangesig (gesig), blootsvoets (kaalvoet), buik (maag), hernieu (bernu), hersenskudding (barsingskudding), bouthakker (boutkapper), luid (hard), naak (kaal), snel (vinnig), spung (spoeg). Overenthusiastic purism led to a great deal of well-established English loan words being branded as Anglicisms - "preferred" or "recommended" substitutes in parentheses: dit sal die dag wees (dank jou die duiwel), iemand a guns doen (iemand a guns bewys), uit iemand se hand eet (na iemand se pype dans), iemand se been trek (met iemand die gek skeer), etc. 
Two centuries of close contact with English turned the Afrikaans vernacular into a mixed language. The Afrikaans vernacular contains thousands of English words and expressions which have been accepted either directly or in a translated form (thus as loan translations):

army, baby, bad, beside(s), broke, bye, ceiling, cherry, cute, down "bek-af", easy, eier, fancy, favourite, fight, flavour, fool, game, girl, hose pipe, image, innings, label, lawn, liar, lucky, mind you, moan, mushrooms, notes, offside, OK, pottery, prawns, shame, size (large, small, medium), smile, stupid, suffer, sweets, twenty-first, yes ...

'n ander ballgame, 'n spanner in die works gooi, aan die einde van die dag, aanpass, afskop, bevolkingsontploffing, blaaskans, blitsverkoper, breinspoel, die bottom line/slotreël, die gap vat, die groen lig gee/hê/kry, die kollig steel/op iets laat val/in die kollig kom, die score ken, game wees, iets uitspel, iets/'n probleem aanspreek, iets/iemand uitsorteer, in 'n flat spin wees, in die prentjie wees/kom/bring, jou customers ken, onkant betrap, op jou baisiekel wees, oppak, skouer aan die wiel sit, systap, van die grond af kom, vir a ses slaan

In addition to the specific language elements discussed above, the standardising influence of the Afrikaans Bible is also pertinent. The polemics following the publication of die Lewende Bybel in 1981 indicated clearly that the Bible Society, at least at the time, regarded other Afrikaans Bible translations as unwanted currency besides those sanctioned by the Society. It was suggested that there should be one single "Standard translation". It must be borne in mind that the reformed churches took the lead in both the 1933 and the 1983 translations.

After 1981, more complete Afrikaans Bible translations were published, in which the theological and language diversity within the Afrikaans language community is clearly embodied and the idea of absolute control of the Afrikaans Bible by the Bible Society and the reformed churches was slackened. This should assist rather than impede future Bible translations. 


\section{BIBLIOGRAPHY}

\section{PONELIS F A}

1993. The development of Afrikaans. Frankfurt: Lang.

1998. Standaardafrikaans en die Afrikaans taalfamilie. Annale van die Universiteit van Stellenbosch 1998/1.

SCHOLTZ J DU P

1965. Die Afrikaner en sy taal. Kaapstad: Nasou.

\section{SNYDERS P}

1987. Afrikaans: taal tussen tale. In: Erasmus G.F. (red.) Afrikaans: horisonne en ideale. Paarl: Afrikaans Taalfonds:68-72.

VAN DER WATT P B

1980. Die Nederduits Gereformeerde Kerk 1824-1905. Pretoria: N.G. Kerk Boekhandel.

\section{VAN ReNSBURG M C J}

1991. Wat van 'n nuwe Afrikaans? Acta Academica 23(3):13-33.

Keywords

Afrikaans

Bible translation 
Abbreviations

\section{ABBREVIATIONS}

$\begin{array}{ll}\text { AV } & \text { Authorised Version (KJV) } \\ \text { BHS } & \text { Biblica Hebraica Stuttgartensia } \\ \text { CEV } & \text { Contemporary English Version } \\ \text { CLT } & \text { Groot Nieuws Bijbel } \\ \text { GNB } & \text { Good News Bible } \\ \text { GNT } & \text { Greek New Testament } \\ \text { JB } & \text { Jerusalem Bible } \\ \text { KJV } & \text { King James Version } \\ \text { NASB } & \text { New American Standard Bible } \\ \text { NAV } & \text { New Afrikaans Version } \\ \text { NBV } & \text { New Dutch Translation (Nieuwe Bijbel Vertaling) } \\ \text { NEB } & \text { New English Bible } \\ \text { NIV } & \text { New International Version } \\ \text { NLT } & \text { New Living Translation } \\ \text { NRSV } & \text { New Revised Standard Version } \\ \text { RSV } & \text { Revised Standard Version } \\ \text { TEV } & \text { Today's English Version } \\ \text { TOB } & \text { Traduction Oecuménique de la Bible }\end{array}$

